\title{
Bacterial and Archaeal Diversity in an Iron-Rich Coastal Hydrothermal Field in Yamagawa, Kagoshima, Japan
}

\author{
SATOSHI KAWAICHI ${ }^{1}$, NORIHIRO ITO ${ }^{1}$, TAKASHI YOSHIDA ${ }^{1}$, and YoShIHIKO SAKO ${ }^{*}$ \\ ${ }^{1}$ Laboratory of Marine Microbiology, Graduate School of Agriculture, Kyoto University, Kyoto 606-8502, Japan
}

(Received April 8, 2013-Accepted July 20, 2013-Published online November 21, 2013)

\begin{abstract}
Physicochemical characteristics and archaeal and bacterial community structures in an iron-rich coastal hydrothermal field, where the temperature of the most active hot spot reaches above $100^{\circ} \mathrm{C}$, were investigated to obtain fundamental information on microbes inhabiting a coastal hydrothermal field. The environmental settings of the coastal hydrothermal field were similar in some degree to those of deep-sea hydrothermal environments because of its emission of $\mathrm{H}_{2}, \mathrm{CO}_{2}$, and sulfide from the bottom of the hot spot. The results of clone analyses based on the 16S rRNA gene led us to speculate the presence of a chemo-synthetic microbial ecosystem, where chemolithoautotrophic thermophiles, primarily the bacterial order Aquificales, function as primary producers using $\mathrm{H}_{2}$ or sulfur compounds as their energy source and $\mathrm{CO}_{2}$ as their carbon source, and the organic compounds synthesized by them support the growth of chemoheterotrophic thermophiles, such as members of the order Thermales and the family Desulfurococcaceae. In addition, the dominance of members of the bacterial genus Herbaspirillum in the high temperature bottom layer led us to speculate the temporal formation of mesophilic zones where they can also function as primary producing or nitrogen-fixing bacteria.
\end{abstract}

Key words: coastal hydrothermal field, thermophiles, chemo-synthetic ecosystem, extremophiles

Hydrothermal systems, where geothermally heated waters are expelled through fissures in the Earth's crust, are located both on land and under the sea. Deep-sea hydrothermal systems are one of the most extensively studied habitats of thermophilic microorganisms, since the first deep-sea hydrothermal vent on the Galapagos Rift and its associated macrofauna were discovered in 1977 (10). In deep-sea hydrothermal systems, where no sunlight penetrates, microbial primary production is achieved by chemolithoautotrophs utilizing $\mathrm{H}_{2}$, sulfur-bearing compounds, and $\mathrm{CO}_{2}(3,6,20$, $21,27,36,55)$. These compounds are provided by magma degassing and reactions between seawater and rock at high temperatures $(6,66)$, and serve as energy (electron donor/ acceptor) and carbon sources.

Compared to deep-sea hydrothermal systems, considerably less is known about the microbial community structures inhabiting shallow-sea systems, such as on-shore seeps and shallow vents. Like their deep-sea counterparts, shallow-sea hydrothermal systems are often found in volcanic regions (e.g. New Zealand, Italy, and Argentina). For example, the presence of shallow vents located in a few meters of water on Vulcano Island, Italy have been known for much longer than deep-sea systems due to their proximity to the shore and easier accessibility and also some microbes have been isolated from the vents $(2,51,56)$. These shallow-sea systems differ from deep-sea systems in a variety of ways. For example, in shallow-sea systems, hydrothermal fluids are much cooler than deep-sea systems where fluids can surpass $400^{\circ} \mathrm{C}$ due to high hydrostatic pressure (4). The chemical composition of hydrothermal fluids is reducing, like deep-sea or terrestrial hydrothermal sites, but shallow-sea system fluids are usually

\footnotetext{
* Corresponding author. E-mail: sako@kais.kyoto-u.ac.jp; Tel: +81-75-753-6217; Fax: +81-75-753-6226.
}

richer in N, P, and Si and do not have such high concentrations of $\mathrm{CH}_{4}$ and $\mathrm{H}_{2}$ as deep-sea systems (66). Shallow-sea vent fluids often contain a meteoric water component (47) and their chemistry can affect near-shore activity and vice versa (46). These unique environmental conditions led us to expect that the microbial inhabitants of shallow-sea hydrothermal fields could be distinct from those of other environments, including deep-sea hydrothermal systems. However, microbial communities in shallow-sea hydrothermal systems have so far garnered less interest than those in their deep-sea counterparts.

The Yamagawa coastal hydrothermal field is located in the Kirishima Volcanic Belt, which is one of the most active volcanic areas in Japan. Recently, two novel thermophilic bacteria were isolated from this environment $(26,61)$. In addition, strains of strictly aerobic, neutrophilic, hyperthermophilic archaeal genus Aeropyrum (Tanaka et al. unpublished data) and two novel strains of virus infecting the type species of the genus Aeropyrum were successfully isolated $(38,39)$. However, no study on the comprehensive microbial community has performed in this environment.

We first determined the fundamental physicochemical characteristics, such as the temperature, pore water characteristics, gas compositions, and the iron content of the sediments in the Yamagawa coastal hydrothermal field. The factors were inferred to have a critical effect on the spectrum of viable microbes in the environment. The compositions of pore water and gas gave information on the availability of electron donors/acceptors and carbon sources in the environment for microbes. Thereafter, we performed cultureindependent analysis targeting the environmental 16S rRNA gene (16S rRNA gene clone analysis) to obtain a snap-shot of the microbial communities inhabiting the Yamagawa coastal hydrothermal field. 


\section{Materials and Methods}

Study site description and sample collection

The study site was a coastal hydrothermal field on the Yamagawa Beach ( $\left.31^{\circ} 10^{\prime} 58^{\prime \prime} \mathrm{N}, 130^{\circ} 36^{\prime} 59^{\prime \prime} \mathrm{E}\right)$ (Fig. 1a), a coarse-grained sandy beach on the southern coast of Kyushu Island (Japan). Several hot spots erupt hot steam on the beach. The most active steam vent (Hot spot No. 6: HS6) was selected and a sampling transect was established through HS6 from the land to the sea (Fig. 1b). Sediments were collected from six points along the transect with different depths and temperatures (Fig. 1c) to determine the amount of ferric iron $(\mathrm{Fe}[\mathrm{III}])$ in the sediments, and for clone analyses. Each sample name is abbreviated to three letters: the first two letters for the temperature zones: HS for hot spot $\left(101^{\circ} \mathrm{C}\right)$, DS for downstream $\left(70^{\circ} \mathrm{C}\right)$, and $\mathrm{RE}$ for reference site $\left(25^{\circ} \mathrm{C}\right)$, and the last letter for depth; $\mathrm{S}$ for surface $(0-5 \mathrm{~cm}$ beneath surface), and B for bottom (approx. $40 \mathrm{~cm}$ beneath surface). Since we could not obtain vertical
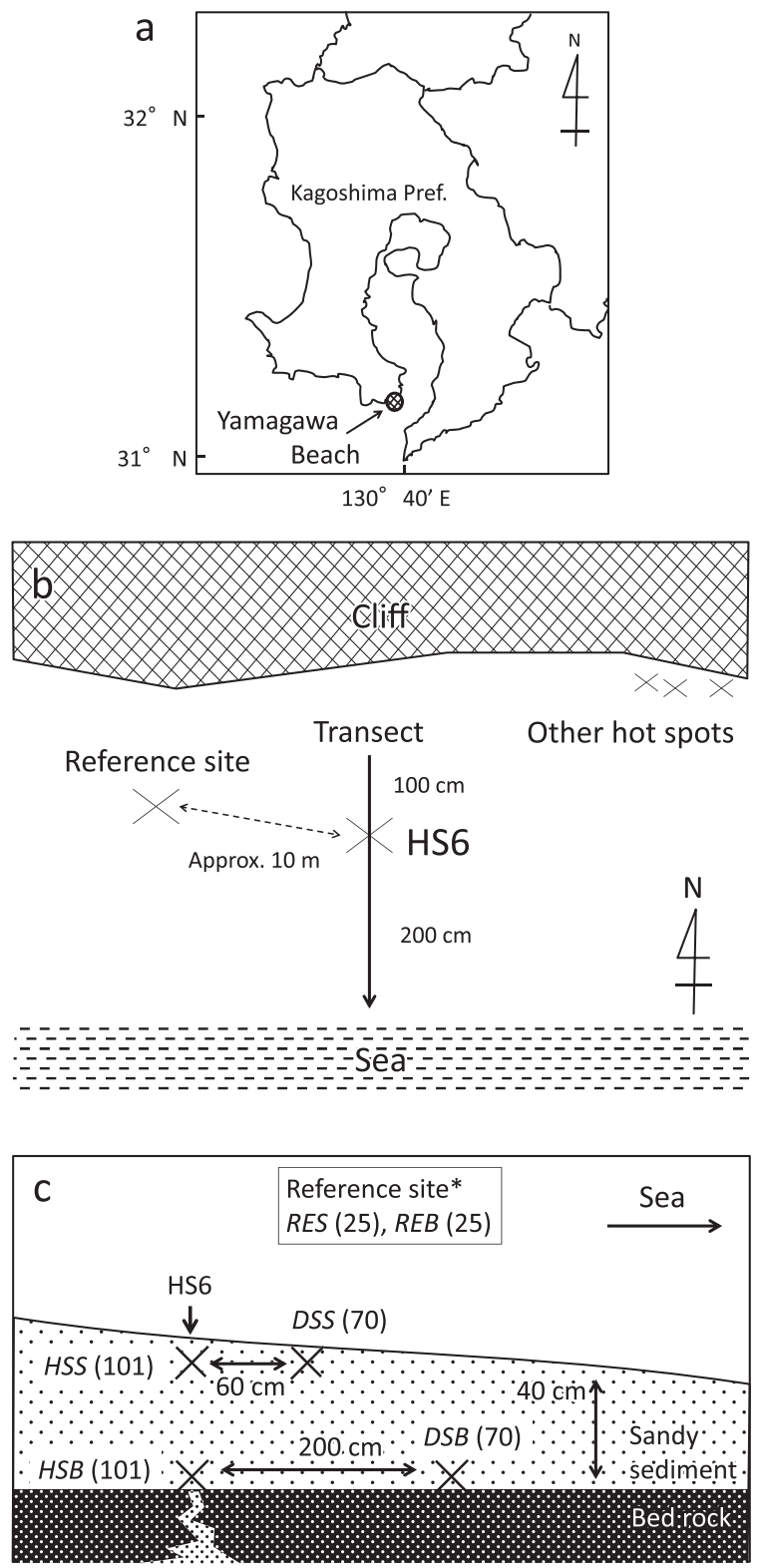

Fig. 1. Location of Yamagawa Beach (a), transect across HS6 (b), and sampling sites in the Yamagawa coastal hydrothermal field (c). Sampling sites are shown in italic. See text for abbreviations. Numbers in parentheses indicate the temperature of the samples. ${ }^{*}$ Reference site is off the transect, approximately $10 \mathrm{~m}$ from HS6. core samples due to the coarse-grained sandy and friable sediments, we dug a hole near each sampling point and collected the sediments using tip-cut syringes. Approximately $40 \mathrm{~g}$ (wet weight) of sediment was immediately transferred into a $50 \mathrm{~mL}$ glass vial and flushed with $100 \% \mathrm{~N}_{2}(100 \mathrm{kPa})$. The vial was closed tightly using a butyl rubber stopper and sealed with a screw cap. No reducing agent was added. Samples were stored at $4{ }^{\circ} \mathrm{C}$ in the dark until used.

\section{Physicochemical measurements}

The vertical temperature profile was determined in situ along the transect using a probe thermometer. Dissolved oxygen (DO), dissolved hydrogen sulfide, and $\mathrm{pH}$ of pore water were determined in situ using a CHEMets Kit for Dissolved Oxygen (K-7512 for 1$12 \mathrm{ppm}$, and K-7501 for 0-1.0 ppm; CHEMetrics, Midland, VA, USA), a twin $\mathrm{pH}$ Compact $\mathrm{pH}$ Meter (Horiba, Kyoto, Japan), and a VISOCOLOR ECO Sulphide kit (Marchery-Nagel, Düren, Germany), respectively. We could not determine DO, dissolved hydrogen sulfide, or $\mathrm{pH}$ of the pore water of the surface layer due to an insufficient amount of pore water.

Gas samples were collected from the bottom layer of each point (a sample was additionally collected from the surface layer of HS6) using a $50 \mathrm{~mL}$ syringe equipped with a $30 \mathrm{~cm}$ length needle. Gas contents were analyzed using gas chromatography (GC-2014; Shimadzu, Kyoto, Japan) equipped with a thermal conductivity detector and a SHINCARBON ST packed column (Shinwa Chemical Industries, Kyoto, Japan). Argon was used as the carrier gas.

Iron contents of the sediments were determined using the method described by Lovley and Phillips (33). This method is based on the reduction of poorly crystalline ferric iron (amorphous Fe[III] oxyhydroxide) by hydroxylamine under acidic conditions and colorimetry using ferrozine (59) as an indicator. Fe(III) exists in a variety of chemical forms. Among them, amorphous Fe(III) oxyhydroxide is known as one of the most preferable form for microbial Fe(III) reduction $(32,40)$. Hydroxylamine extraction is more selective for amorphous Fe(III) oxyhydroxide than acid ammonium oxalate extraction (33).

\section{DNA extraction and PCR amplification of bacterial and archaeal 16S rRNA genes}

Genomic DNA for clone libraries was extracted from approximately $10 \mathrm{~g}$ of each sediment sample using an UltraClean Mega Soil DNA Isolation Kit (MO BIO Laboratories, Carlsbad, CA, USA) and the obtained DNA $(8 \mathrm{~mL})$ was concentrated to a volume of 500 $\mu \mathrm{L}$ with distilled water by following the manufacturer's instructions. Bacterial and archaeal 16S rRNA genes were amplified by PCR using primers Bac27F (30) and Bac907R (41) for bacterial rRNA genes and primers Arch21F and Arch958R (11) for archaeal rRNA genes. Resultant PCR products were purified using an MinElute Gel Extraction Kit (Qiagen, Venlo, Netherlands). The purified DNA was cloned in the vector pCR2.1 using the Original TA cloning kit (Invitrogen, Carlsbad, CA, USA). The inserts were amplified by direct PCR from a single colony using a primer set of M13 primer M4 (5'-GTT TTC CCA GTC ACG AC-3') and M13 primer RV (5'-CAG GAA ACA GCT ATG AC-3'), treated with exonuclease I and shrimp alkaline phosphatase (Amersham Pharmacia Biotech, Uppsala, Sweden), and directly sequenced. Primers Bac27F and Arch $21 \mathrm{~F}$ were used in partial sequencing analysis for Bacteria and for Archaea, respectively. Sequences shorter than $300 \mathrm{bp}$ were omitted from further analyses.

\section{Sequence analysis}

The rRNA gene sequences with $\geq 95 \%$ similarity were assigned to the same clone type (Operational Taxonomic Unit, OTU) in both bacterial and archaeal libraries using the FastGroupII program (69). Also, a representative rRNA gene clone of each OTU was determined and rarefaction curves were obtained for each clone library using the same program. Each representative sequence was subjected to an initial pre-classification step using the RDP classifier (67), in which unclassified sequences (not Archaea or Bacteria) or sequences 
classified into the incorrect domain (e.g. Bacteria in the archaeal data set) were removed. Each OTU was assigned to a phylum (for Bacteria, instead of proteobacterial OTUs, which were assigned to a class) or to a family (for Archaea) using the RDP classifier (67) set at a bootstrap value of $80 \%$ (9). Manual classification using maximum-likelihood (ML) trees (described below) and the Blastn search were also performed for unclassified OTUs, since some known lineages (e.g. Thaumarchaeota) were not classified by the RDP classifier.

\section{Phylogenetic analyses}

The obtained representative sequences of each OTU were subjected to a BLASTN search (NCBI: http//www.ncbi.nlm.nih.gov/). The best hit sequence for each representative sequence was collected and used along with the sequences obtained in this study for the following phylogenetic analyses. In order to determine the phylogenetic positions of the representative sequences, sequences were aligned using the ClustalW program (31) available online at the DDBJ (DNA Data Bank of Japan) web site. The ML trees were inferred by the PhyML program in the Phylogeny.fr. platform (12, 19).

\section{Comparison of clone libraries}

Differences in bacterial and archaeal 16S rRNA gene libraries (beta-diversity) were assessed using phylogeny-based metrics, UniFrac (34). Sequences were subjected to the UniFrac program with their "environment file," which describes the source sample of each sequence and the ML tree obtained as described above. UniFrac distances were calculated to account for the abundance of individual taxa (weighted-UniFrac PCA [principal coordinates analysis]). While the libraries consist of different numbers of sequences, UniFrac PCA with a normalized algorithm was performed.

The sequences reported in this study were deposited in the DDBJ database under DDBJ/EMBL/GenBank accession numbers AB812106-AB812548.

\section{Quantitative analyses of bacterial and archaeal $16 \mathrm{~S} r R N A$ genes}

The bacterial and archaeal 16S rRNA genes in each sample were quantified by a quantitative fluorescent PCR method using the Thermal Cycler Dice Real Time System Single (TaKaRa Bio, Otsu, Japan), and SYBR Premix Ex Taq (TaKaRa Bio) and SYBR Premix Ex Taq II (TaKaRa Bio) were used for quantitative detection of the bacterial 16S rRNA gene and archaeal 16S rRNA gene, respectively, following the manufacturer's protocol as previously described (68), while the reaction volume was reduced to $12.5 \mu \mathrm{L}$. For bacterial and archaeal 16S rRNA genes, respectively, primer sets 338f-518r and $931 \mathrm{f}-\mathrm{m} 1100 \mathrm{r}$ were used as described previously (15). For external standards, we used genomic DNA of Escherichia coli DH5 $\alpha$ for the bacterial 16S rRNA gene, and Aeropyrum pernix $\mathrm{K}^{\mathrm{T}}{ }^{\mathrm{T}}$ (= JCM $9820^{\mathrm{T}}$ ) for the archaeal 16S rRNA gene.

\section{Results and Discussion}

\section{Physicochemical characteristics}

The maximum temperature of the sediment in the bottom layer (approximately $30 \mathrm{~cm}$ beneath sediment surface) of HS6 was $104^{\circ} \mathrm{C}$ with an average temperature of $101^{\circ} \mathrm{C}$ (Table $1)$. The temperature of the sediment decreased in proportion to the distance from HS6. A steep gradient of temperature $\left(101^{\circ} \mathrm{C}-26.7^{\circ} \mathrm{C}\right.$ in $\left.70 \mathrm{~cm}\right)$ was present in the sediments along the transect.

A high amount of sulfide was dissolved in the hot fluid from the bottom of HS6 (Table 2). Gas emitted from the bottom of HS6 predominantly contained $\mathrm{CO}_{2}$ (approximately $60 \%$ of total gas content) and a modest amount of $\mathrm{H}_{2}$ (approximately $0.3 \%$ of total gas content) was also detected. These anaerobic gasses were also detected from the bottom layer of the sediment at approximately $70^{\circ} \mathrm{C}\left(\mathrm{CO}_{2}: 40 \%, \mathrm{H}_{2}\right.$ : $0.3 \%$ ). These gases decreased with increasing distance from

Table 1. Temperature distribution along the transect

\begin{tabular}{|c|c|c|c|c|c|c|c|c|c|c|c|}
\hline \multirow{2}{*}{$\begin{array}{l}\text { Depth } \\
\text { (cm) }\end{array}$} & \multicolumn{11}{|c|}{ Distance from HS6 $(\mathrm{cm})$} \\
\hline & -100 & -70 & -60 & -50 & 0 & 40 & 50 & 60 & 70 & 100 & 200 \\
\hline 0 & 24.4 & 29.2 & 92.7 & 101 & 101 & 101 & 90 & 75 & 26.7 & 24.1 & 24 \\
\hline 10 & 24.7 & 50 & 101 & 101 & 101 & 101 & 101 & 101 & 101 & 38.1 & 32.3 \\
\hline 20 & 24.7 & 100 & 101 & 101 & 101 & 101 & 101 & 101 & 101 & 75.4 & 58.5 \\
\hline 30 & 24.9 & 101 & 101 & 101 & 101 & 101 & 101 & 101 & 101 & 99 & $90.1(25)^{\mathrm{a}}$ \\
\hline 40 & 25.3 & $100.8(35)^{\mathrm{a}}$ & 101 & 101 & 101 & 101 & 101 & 101 & 101 & $100.5(35)^{\mathrm{a}}$ & nd \\
\hline
\end{tabular}

nd, not determined.

a Numbers in parentheses indicate depth.

Table 2. Physicochemical characteristics of hot fluids and gasses along the transect

\begin{tabular}{|c|c|c|c|c|c|c|c|c|c|c|}
\hline \multirow{2}{*}{$\begin{array}{l}\text { Distance from } \\
\text { HS6 }(\mathrm{cm})\end{array}$} & \multirow{2}{*}{$\begin{array}{l}\text { Depth } \\
(\mathrm{cm})\end{array}$} & \multirow{2}{*}{$\begin{array}{l}\text { Temp. } \\
\left({ }^{\circ} \mathrm{C}\right)\end{array}$} & \multicolumn{3}{|c|}{ Hot fluids } & \multicolumn{5}{|c|}{ Gas contents $(\%)$} \\
\hline & & & $\mathrm{pH}^{\mathrm{a}}$ & $\begin{array}{c}\mathrm{DO} \\
(\mathrm{ppm})^{\mathrm{a}}\end{array}$ & $\begin{array}{c}\mathrm{H}_{2} \mathrm{~S} \\
(\mathrm{ppm})^{\mathrm{a}}\end{array}$ & $\mathrm{H}_{2}$ & $\mathrm{O}_{2}$ & $\mathrm{~N}_{2}$ & $\mathrm{CH}_{4}$ & $\mathrm{CO}_{2}$ \\
\hline 0 & 30 & 101.0 & 7.6 & 1 & 0.8 -over & 0.28 & bd & 27.31 & bd & 57.48 \\
\hline 50 & 30 & 101.0 & 6.1 & 1 & 0.8 -over & 0.26 & 5.07 & 59.23 & bd & 40.46 \\
\hline 100 & 30 & 99.0 & nd & nd & nd & bd & 23.02 & 75.23 & bd & 4.11 \\
\hline $\mathrm{REB}^{\mathrm{b}}$ & 30 & 24.0 & 7.9 & 5 & 0.2 & bd & 12.23 & 89.42 & bd & bd \\
\hline
\end{tabular}

nd, not determined; bd, below the detection limits.

${ }^{a}$ The $\mathrm{pH}$, dissolved $\mathrm{O}_{2}$ concentration and dissolved $\mathrm{H}_{2} \mathrm{~S}$ concentration at the reference site refers to those of air-saturated seawater.

${ }^{b}$ REB, Bottom layer of the ordinary temperature zone (see text). 
HS6. Oxygen was not detected in the gas emitted from the bottom of HS6, while hot fluid from the same point contained a modest amount of dissolved oxygen (1 ppm). Despite vigorous steam emission, the gas contents of the surface layer of HS6 were similar to those of atmospheric air. Dissolved sulfide also decreased with increasing distance from the bottom of HS6 (Table 2). This indicates the presence of an anaerobic zone near the bottom of HS6 and microaerobic to aerobic zones surrounding it. $\mathrm{CO}_{2}, \mathrm{H}_{2}$, and sulfide emitted from the bottom of HS6 could serve as a carbon source and as an electron donor for chemolithoautotrophic microbes in the anaerobic zone. Coarse-grained sandy sediments may allow diffusion of these anaerobic gasses and reducing compounds (sulfide) from the bottom of HS6 to the surrounding zones, while atmospheric air diffuses from the surface layer.

Sandy sediments consist of volcanic rocks such as basalt, pyroxene, olivine, and pumice. These minerals are known to bear substantial amounts of iron and aluminum. The amount of Fe(III) in the surface sediments showed a clear declining trend with distance from the hot spot (15.7-6.5 $\mu \mathrm{mol}$ per $\mathrm{g}$ sediment), while those of bottom sediments showed an increasing trend (3.0-6.5 $\mu \mathrm{mol}$ per g sediment) (Fig. 2).

Thus, HS6 included physicochemical settings similar to those of a deep-sea hydrothermal vent, i.e. steep gradient of temperature, reducing power $\left(\mathrm{H}_{2}\right.$ and sulfide $)$ and $\mathrm{CO}_{2}$ emission from the subsurface, presence of anaerobic zone with high temperature, and the presence of abundant Fe(III). On the other hand, the steep gradient of oxygen discriminates HS6 from deep-sea hydrothermal vents, which is derived from anaerobic gas emission from the bottom layer and direct exposure to atmospheric air.

\section{Microbial community analyses}

From the 12 clone libraries, 443 sequences with an average length of 597 bp (341-720 bp and 453-767 bp for Archaea and Bacteria, respectively) were investigated. Rarefaction analyses showed that bacterial communities are much more diverse than archaeal communities (Fig. S1). Normalized weighted UniFrac PCA revealed that both archaeal and bacterial communities of the HSB sample were distinct from those of other samples (Figs. S2 and 4, respectively). Bacterial community compositions of the samples clustered in three groups: high temperature and anaerobic sample (HSB),

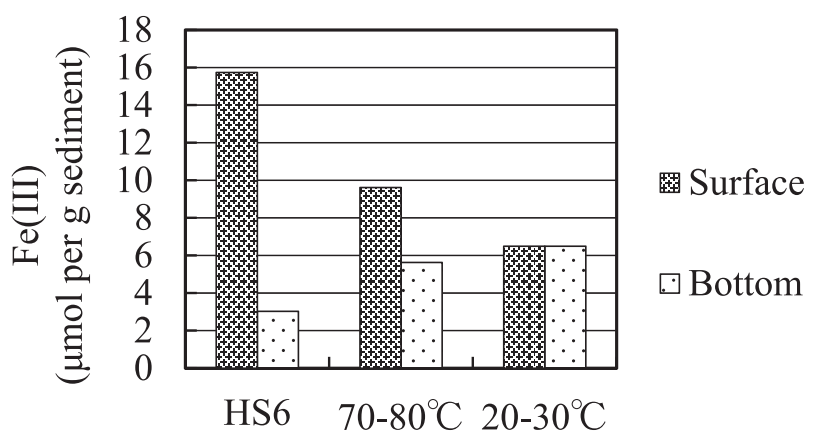

Temperature zones

Fig. 2. Fe(III) content of sediment samples from HS6 and its adjacent sites. Data are from a single trial.

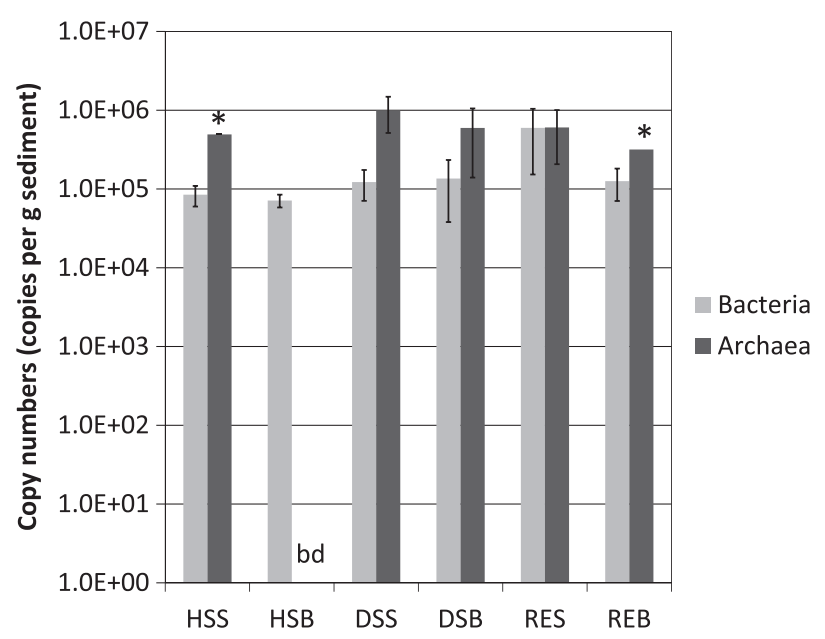

Fig. 3. Comparison of bacterial and archaeal $16 \mathrm{~S}$ rRNA genes copy numbers. *data which were not detected in one sample of triplicate experiments. bd, below detection limit of $1.7 \times 10^{3}$ copies. Error bars showing standard deviation.

microaerobic to aerobic, high temperature samples (HSS, DSS, and DSB), and ordinary temperature samples (RES and REB) (Fig. 4). Quantitative PCR revealed the low biomass $\left(7.1 \times 10^{4}-1.2 \times 10^{6} 16 \mathrm{~S}\right.$ rRNA gene copies per $\mathrm{g}$ sediment for total bacteria and archaea) of this environment (Fig. 3).

In archaeal communities, the most striking difference between HSB and other samples was the predominance of hyperthermophilic Crenarchaeota (Desulfurococcaceae, Pyrodictiaceae, and Thermoproteaceae) at HSB (Fig. 5). Sequences assigned to the family Desulfurococcaceae were closely related to the genus Aeropyrum (Table S1). In addition to the detection of relative clone sequences, the isolation of strains affiliated in this genus (Tanaka et al. unpublished

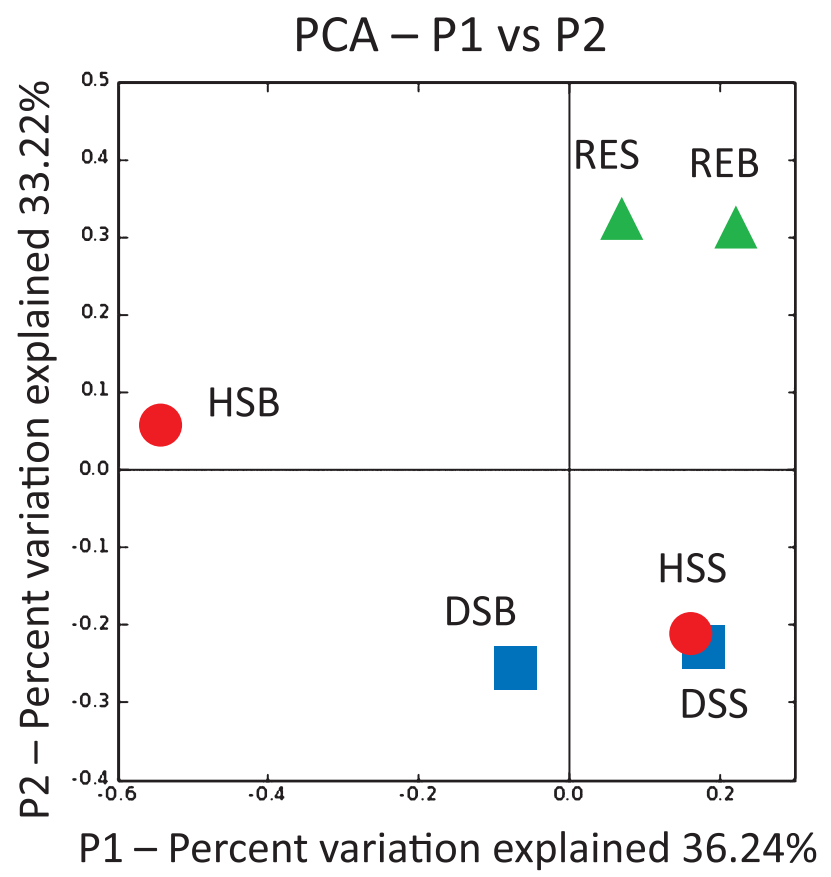

Fig. 4. Communities clustered using normalized weighted-UniFrac PCA for bacterial communities. Each point represents an individual sample. 


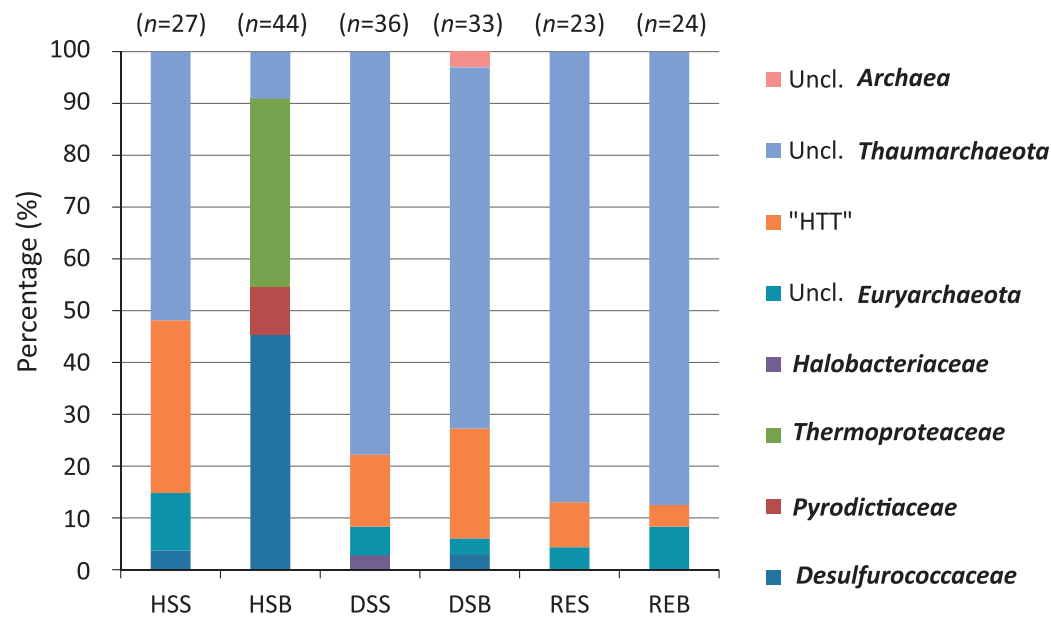

Fig. 5. Comparison of taxonomic variation in the archaeal communities of the Yamagawa coastal hydrothermal field. Relative abundance of archaeal families observed in each sample are shown. Numbers in parentheses indicate the numbers of clone sequences. "HTT" (hydrothermal field Thaumarchaeota) indicates a cluster affiliated with sequences of Thaumarchaeota obtained from hydrothermal fields. Uncl., unclassified.

data) and two novel strains of virus infecting the members of this genus $(38,39)$ ensured the inhabitation of this hyperthermophilic archaeon in this environment. The genus Aeropyrum consists of two species, $A$. pernix and $A$. camini, originally isolated from a shallow hydrothermal vent (53) and from a deep-sea hydrothermal vent (42), respectively. Both species are strictly aerobic heterotrophic hyperthermophiles. Clones assigned to the family Pyrodictiaceae were most closely related to Geogemma indica strain $296^{\mathrm{T}}$ or clone sequences obtained from deep-sea hydrothermal vents (Table S1). The family Pyrodictiaceae consists of anaerobic hyperthermophiles optimally grow at temperatures above $100^{\circ} \mathrm{C}$, such as the genera Pyrodictium $(45,58)$, Geogemma (22), Hyperthermus (70, 71), and Pyrolobus (5). The sequences assigned to the family Thermoproteaceae were related to the genus Pyrobaculum and most closely related to an isolate from Obama Hot Spring (Table S1), which is a coastal hot spring located approximately $180 \mathrm{~km}$ north of the Yamagawa coastal hydrothermal field. The members of the genus Pyrobaculum are hyperthermophilic facultative anaerobes. The members of the family Pyrodictiaceae and the genus Pyrobaculum grow heterotrophically or chemolithoautotrophically using molecular $\mathrm{H}_{2}$ as an electron donor.

Archaeal sequences obtained from the samples other than HSB were dominated by sequences affiliated to Thaumarchaeota, a recently described archaeal phylum ubiquitously detected from various environments $(7,44)$. The archaeal ML tree indicated that the sequences affiliated to Thaumarchaeota were clustered in two groups (Fig. 6). One of the two (referred to as "HTT" group) consists of sequences obtained from hydrothermal fields around the world, such as Tutum Bay, an iron- and arsenic-rich shallow-sea hydrothermal field in Papua New Guinea $(1,37)$. Although, unfortunately, metal compositions of other environments are not available, it can be assumed that the hydrothermal sulfide structure and deep-sea chimney wall consist of a modest amount of iron, because the accumulation of iron by the mixing of hydrothermal fluids and cold ambient seawaters is the most important process in the formation of these metallic-sulfide structures. Despite its ubiquitous distribution, the phylum consists of few isolates $(29,63)$. Thus, the functions of the members of this phylum attracted our interest. In light of the distribution of "HTT" in HS6, members of this group might be adapted to iron-rich environments at either high or moderate temperatures, although considerable effort is needed to speculate the functions of microbes from their phylogeny.

Overall, the bacterial community of the Yamagawa coastal hydrothermal field consists of diverse taxa, including both thermophiles and mesophiles. The only bacterial order shared by all samples was Rhodobacterales of the phylum Alphaproteobacteria (Fig. 7, Table S2). The order is phenotypically, metabolically, and ecologically diverse (18). However, many of them are aquatic and require $\mathrm{NaCl}$ for growth. Including Rhodobacterales, most bacterial clones were relative to clone sequences retrieved from marine environments around the world.

Like the archaeal communities, HSB community significantly differed from those of other samples. The phylum Betaproteobacteria represented the largest fraction (37.1\%) in HSB (Fig. 7, Table S2). The sequences affiliated to this phylum, except one sequence, were closely related to the genus Herbaspirillum (Table S2). The species of this genus mainly comprise diazotrophic bacteria with potential for endophytic and systemic colonization of a variety of plants $(13,14,28,52,64)$. All of the validly described species are mesophilic heterotrophs, except one autotrophic species (13). Contrary to the mesophilic physiology of the known isolates, clone sequences affiliated to this genus are often detected around hydrothermal fields $(25,60)$. In some studies, the predominantly detected Herbaspirillum is conjectured to be a result of contamination through DNA extraction or cloning procedures (62). However, while these environments harbored a steep temperature gradient, it can be assumed that the members of this genus were detected in hydrothermal fields due to the presence of mesophilic (micro) habitats. In case of the Yamagawa hydrothermal field, mesophilic zones may temporally occur around HSB due to tidal activity, thus providing favorable habitats for Herbaspirillum. In addition to nitrogen-fixing heterotrophic growth, some isolates affil- 


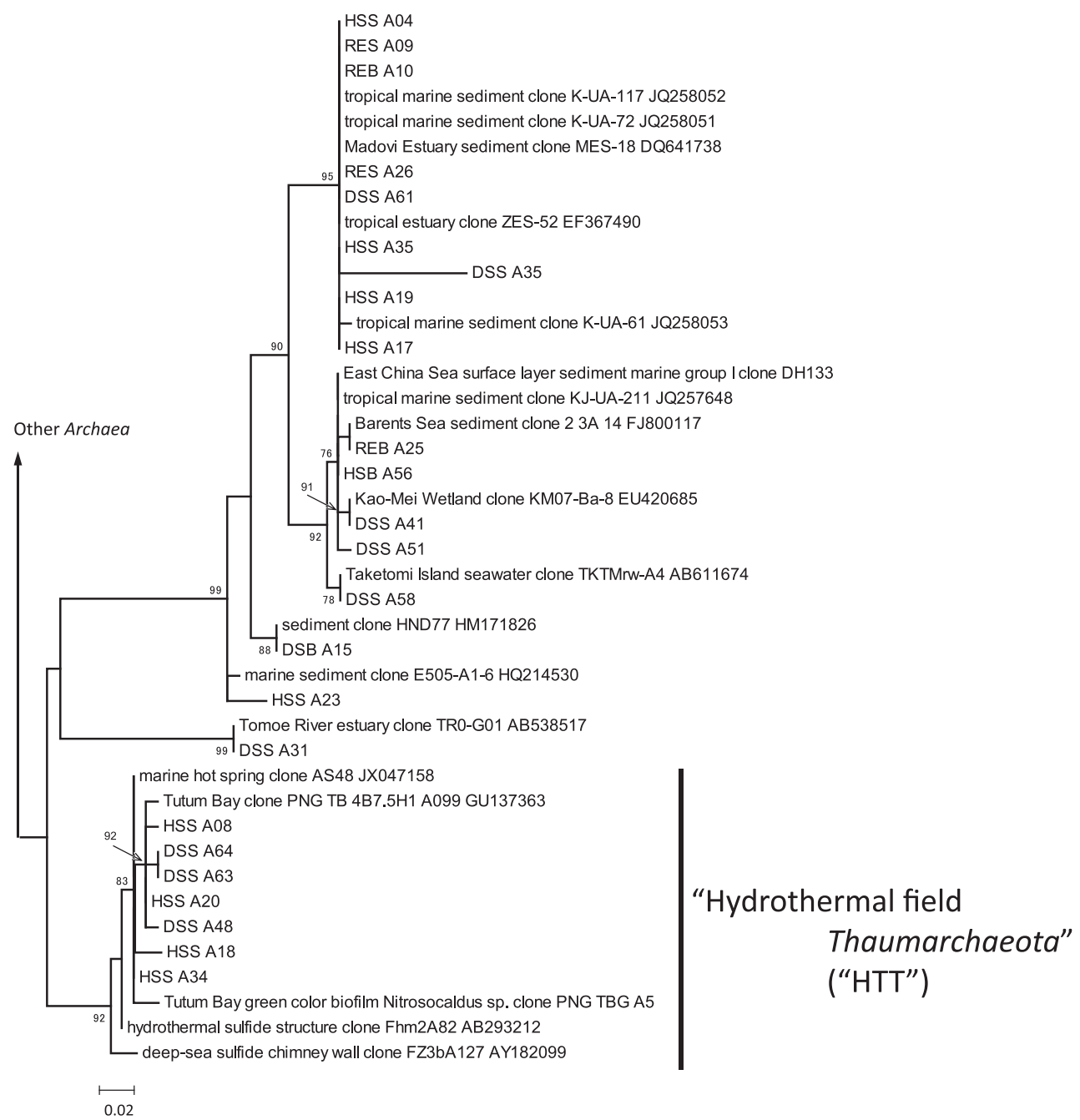

Fig. 6. ML tree of the archaeal phylum Thaumarchaeota. ML bootstrap values $\geq 75 \%$ are shown at each node. Environmental clone sequences are described by their specific names and GenBank/EMBL/DDBJ accession numbers.

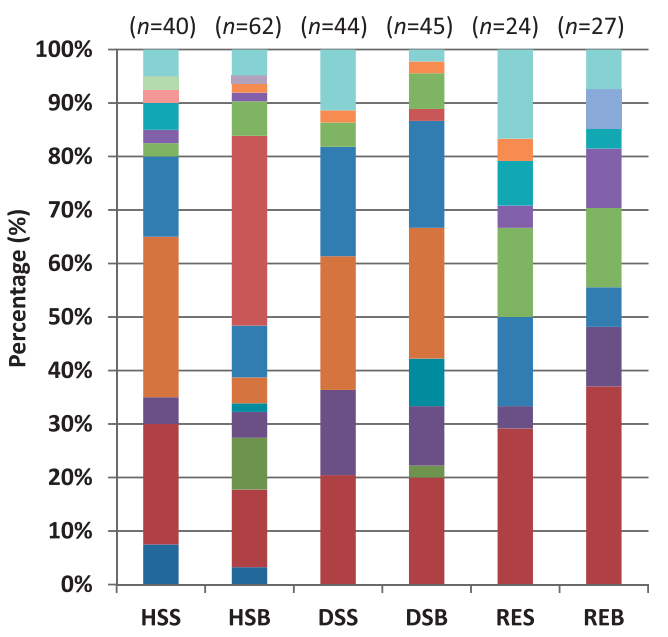

Uncl. Bacteria

- Uncl. Proteobacteria

Uncl. Actinobacteria

- TM7

Nitrospira

- Planctomycetes

Chloroflexi

- Deltaproteobacteria

- Gammaproteobacteri

- Betaproteobacteria

- Alphaproteobacteria

- Firmicutes

Deinococcus-

- Bacteroidetes

- Aquificae

- Actinobacteria

- Acidobacteria
Fig. 7. Comparison of taxonomic variation in the bacterial communities of the Yamagawa coastal hydrothermal field.

Relative abundance of bacterial orders observed in each sample is shown. Numbers in parentheses indicate the numbers of clone sequences. Uncl., unclassified. iated to this genus are reported to grow chemolithoautotrophically using $\mathrm{H}_{2}$ and $\mathrm{CO}_{2}$ as their energy and carbon sources $(13,37)$. Considering the low biomass in HSB revealed by quantitative PCR (Fig. 3), dominantly detected Herbaspiril- lum may be inferred to be one of the primary producers in HSB during high tide. Another mesophilic bacterial phylum, Firmicutes, was also detected from high temperature samples (HSS, HSB, DSS, and DSB) (4.8-30.0\%) (Fig. 7, Table S2). 
Unlike the genus Herbaspirillum, this order mainly consists of spore-forming bacteria (54). Thus, the detection could be the result of amplification of the 16S rRNA gene of their spores.

Two thermophilic bacterial phyla, Aquificae and Deinococcus-Thermus, were detected from HSB and DSB (Fig. 7). All four sequencesidentified as Deinococcus-Thermus were relatives of an isolate from a deep-sea hydrothermal vent, presumably representing a novel species affiliated to the genus Rhabdothermus (Kawaichi et al. in preparation). Like other genera in the order Thermales, the only described species of the genus Rhabdothermus, $R$. arcticus, is a heterotrophic thermophile (57). $R$. arcticus requires $\mathrm{NaCl}$ for its growth, grows under microaerobic conditions, and is also capable of anaerobic respiration in the presence of either nitrate or elemental sulfur. The other thermophilic bacterial phylum, Aquificae, is a group of thermophilic autotrophic bacteria capable of oxidation of molecular $\mathrm{H}_{2}$, thiosulfate, and $\mathrm{S}^{0}$, and reduction of $\mathrm{O}_{2}, \mathrm{~S}^{0}$, and nitrate $(17,43,48)$. The members of this phylum have been found in hot springs and deep-sea hydrothermal vents as primary carbon fixers (49, 50). Combining these findings with the results of quantitative PCR targeting bacterial and archaeal 16S rRNA genes showing that archaeal 16S rRNA genes were below the detection limit in HSB, it is suggested that members of Aquificae are the main primary producers, contributing more than autotrophic and mixotrophic archaea.

\section{Chemo-synthetic ecosystem in HS6}

Our data showed the emission of $\mathrm{H}_{2}, \mathrm{CO}_{2}$, and sulfide from the bottom of HS6, and also the presence of high iron content and steep gradients of temperature around the hotspot. The emission of $\mathrm{H}_{2}, \mathrm{CO}_{2}$, and sulfide might provide favorable habitats for anaerobic chemolithoautotrophic microbes, and abundant ferric iron might be an energetically favorable electron acceptor for some microbes in anaerobic environments due to its high redox potential. It can also be assumed that sulfide provided from hot fluids will be oxidized abiotically by oxygen in the air or in ambient seawater, and then provide $\mathrm{S}^{0}$ or thiosulfate, which can serve as electron donors or electron acceptors for chemolithoautotrophic microbes. In fact, clone analysis revealed the presence of chemolithoautotrophic thermophiles capable of oxidation of $\mathrm{H}_{2}$ and oxidation or reduction of sulfur compounds (the bacterial order Aquificales and the archaeal families Thermoproteaceae and Pyrodictiaceae) in the HSB.

These findings inferred the presence of a microbial ecosystem in HS6 based on the chemical energy source provided by HSB. Namely, chemolithoautotrophic thermophiles, mainly Aquificae, function as primary producers using $\mathrm{H}_{2}$ or sulfur compounds as their energy source and $\mathrm{CO}_{2}$ as their carbon source. The organic compounds synthesized by them support the growth of thermophilic heterotrophs, socalled "chemo-synthetic microbial ecosystems." Of course, as many mesophilic microbes were detected from the samples, these microbes may possibly serve as part of the energy and carbon sources for this ecosystem.

Some strains of the archaeal genus Pyrobaculum and most members of the archaeal family Pyrodictiaceae grow by $\mathrm{Fe}$ (III) reduction and also by reduction of sulfur compounds such as $\mathrm{S}^{0}$ and thiosulfate $(8,16,22,23,24,65)$. Despite the presence of iron-bearing rocks, no well-known bacterial iron reducers, such as the members of the genera Geobacter and Shewanella, were detected in this study. In fact, the isolation of an iron reducer affiliated to the phylum Chloroflexi, which is the first report of this ability in the phylum, was achieved using sandy sediment from this environment (26). Since the ability to grow by dissimilatory Fe(III) reduction is species or even strain specific, further studies, especially based on culture-dependent approaches, are necessary to reveal the effect of the high amount of iron in this environment on the bacterial (and also archaeal) community.

\section{Acknowledgements}

We are grateful to Ken Takai, Takuro Nunoura, Satoshi Nakagawa, and Miho Hirai for their support of clone analysis. SK was a research fellow supported by JSPS for Young Scientists (No. 203694). This work was partially supported by a Grant-in-Aid for Scientific Research (No. 20248023) from The Ministry of Education, Culture, Sports, Science and Technology.

\section{References}

1. Akerman, N.H., R.E. Price, T. Pichler, and J.P. Amend. 2011. Energy sources for chemolithotrophs in an arsenic- and iron-rich shallow-sea hydrothermal system. Geobiology. 9:436-445.

2. Amend, J.P., D.R. Meyer-Dombard, S.N. Sheth, N. Zolotova, and A.C. Amend. 2003. Palaeococcus helgesonii sp. nov., a facultatively anaerobic, hyperthermophilic archaeon from a geothermal well on Vulcano Island, Italy. Arch Microbiol. 179:394-401.

3. Amend, J.P., and E.L. Shock. 2001. Energetics of overall metabolic reactions of thermophilic and hyperthermophilic Archaea and Bacteria. FEMS Microbiol Rev. 25:175-243.

4. Baross, J., and S. Hoffman. 1985. Submarine hydrothermal vents and associated gradient environments as sites for the origin and evolution of life. Origins Life Evol Biosphere. 15:327-345.

5. Blöchl, E., R. Rachel, S. Burggraf, D. Hafenbradl, H.W. Jannasch, and K.O. Stetter. 1997. Pyrolobus fumarii, gen. and sp. nov., represents a novel group of archaea, extending the upper temperature limit for life to $113^{\circ} \mathrm{C}$. Extremophiles. 1:14-21.

6. Brazelton, W.J., B. Nelson, and M.O. Schrenk. 2012. Metagenomic evidence for $\mathrm{H}_{2}$ oxidation and $\mathrm{H}_{2}$ production by serpentinite-hosted subsurface microbial communities. Front Microbiol. 2:268, doi:10.3389/fmicb.2011.00268.

7. Brochier-Armanet, C., B. Boussau, S. Gribaldo, and P. Forterre. 2008. Mesophilic crenarchaeota: proposal for a third archaeal phylum, the Thaumarchaeota. Nat Rev Micro. 6:245-252.

8. Childers, S., and D. Lovley. 2001. Differences in Fe(III) reduction in the hyperthermophilic archaeon, Pyrobaculum islandicum, versus mesophilic Fe(III)-reducing bacteria. FEMS Microbiol Lett. 195:253258.

9. Claesson, M.J., O. O’Sullivan, Q. Wang, J. Nikkilä, J.R. Marchesi, H. Smidt, W.M. de Vos, R.P. Ross, and P.W. O'Toole. 2009. Comparative analysis of pyrosequencing and a phylogenetic microarray for exploring microbial community structures in the human distal intestine. PLoS One. 4:e6669.

10. Corliss, J.B., J. Dymond, L.I. Gordon, et al. 1979. Submarine thermal springs on the Galapagos rift. Science. 203:1073-1083.

11. DeLong, E. 1992. Archaea in coastal marine environments. Proc Natl Acad Sci U.S.A. 89:5685-5689.

12. Dereeper, A., V. Guignon, G. Blanc, et al. 2008. Phylogeny.fr: robust phylogenetic analysis for the non-specialist. Nucl Acids Res. 36:W465-W469.

13. Ding, L., and A. Yokota. 2004. Proposals of Curvibacter gracilis gen. nov., sp. nov. and Herbaspirillum putei sp. nov. for bacterial strains isolated from well water and reclassification of [Pseudomonas] huttiensis, [Pseudomonas] lanceolata, [Aquaspirillum] delicatum and [Aquaspirillum] autotrophicum as Herbaspirillum huttiense comb. nov., Curvibacter lanceolatus comb. nov., Curvibacter delicatus comb. nov. and Herbaspirillum autotrophicum comb. nov. Int J Syst Evol Microbiol. 54:2223-2230. 
14. Dobritsa, A.P., M.C.S. Reddy, and M. Samadpour. 2010. Reclassification of Herbaspirillum putei as a later heterotypic synonym of Herbaspirillum huttiense, with the description of $H$. huttiense subsp. huttiense subsp. nov. and $H$. huttiense subsp. putei subsp. nov., comb. nov., and description of Herbaspirillum aquaticum sp. nov. Int J Syst Evol Microbiol. 60:1418-1426.

15. Einen, J., I.H. Thorseth, and L. Øvreås. 2008. Enumeration of Archaea and Bacteria in seafloor basalt using real-time quantitative PCR and fluorescence microscopy. FEMS Microbiol Lett. 282:182187

16. Feinberg, L.F., and J.F. Holden. 2006. Characterization of dissimilatory $\mathrm{Fe}(\mathrm{III})$ versus $\mathrm{NO}_{3}{ }^{-}$reduction in the hyperthermophilic archaeon Pyrobaculum aerophilum. J Bacteriol. 188:525-531.

17. Götz, D., A. Banta, T.J. Beveridge, A.I. Rushdi, B.R.T. Simoneit, and A.L. Reysenbach. 2002. Persephonella marina gen. nov., sp. nov. and Persephonella guaymasensis sp. nov., two novel, thermophilic, hydrogen-oxidizing microaerophiles from deep-sea hydrothermal vents. Int J Syst Evol Microbiol. 52:1349-1359.

18. Garrity, G.M., J.A. Bell, and T. Lilburn. 2005. Order III. Rhodobacterales ord. nov., p. 161-229. In D. Brenner, N. Krieg, G. Garrity, J. Staley, D. Boone, P. Vos, M. Goodfellow, F. Rainey, and K.-H. Schleifer (ed.), Bergey's Manual of Systematic Bacteriology, vol. 2. Springer, New York.

19. Guindon, S., J. Dufayard, V. Lefort, M. Anisimova, W. Hordijk, and O. Gascuel. 2010. New algorithms and methods to estimate maximum-likelihood phylogenies: assessing the performance of PhyML 3.0. Syst Biol. 59:307-321.

20. Jannasch, H.W. 1995. Microbial interactions with hydrothermal fluids, p. 273-296, Seafloor Hydrothermal Systems: Physical, Chemical, Biological, and Geological Interactions, vol. 91. AGU, Washington, DC.

21. Karl, D.M., C.O. Wirsen, and H.W. Jannasch. 1980. Deep-sea primary production at the Galapagos hydrothermal vents. Science 207:1345-1347.

22. Kashefi, K., and D. Lovley. 2003. Extending the upper temperature limit for life. Science 301:934.

23. Kashefi, K., and D. Lovley. 2000. Reduction of Fe(III), Mn(IV), and toxic metals at 100 degrees $\mathrm{C}$ by Pyrobaculum islandicum. Appl Environ Microbiol. 66:1050-1056.

24. Kashefi, K., B. Moskowitz, and D. Lovley. 2008. Characterization of extracellular minerals produced during dissimilatory $\mathrm{Fe}(\mathrm{III})$ and $\mathrm{U}(\mathrm{VI})$ reduction at 100 degrees $\mathrm{C}$ by Pyrobaculum islandicum. Geobiology. 6:147-154

25. Kato, S., K. Yanagawa, M. Sunamura, et al. 2009. Abundance of Zetaproteobacteria within crustal fluids in back-arc hydrothermal fields of the Southern Mariana Trough. Environ Microbiol. 11:3210 3222 .

26. Kawaichi, S., N. Ito, R. Kamikawa, T. Sugawara, T. Yoshida, and Y. Sako. 2013. Ardenticatena maritima gen. nov., sp. nov., a ferric ironand nitrate-reducing bacterium of the phylum Chloroflexi isolated from an iron-rich coastal hydrothermal field, and description of Ardenticatenia classis nov. Int J Syst Evol Microbiol. 63:2992-3002.

27. Kelley, D.S., J.A. Karson, G.L. Früh-Green, et al. 2005. A serpentinite-hosted ecosystem: the Lost City hydrothermal field. Science 307:1428-1434.

28. Kirchhof, G., B. Eckert, M. Stoffels, J.I. Baldani, V.M. Reis, and A. Hartmann. 2001. Herbaspirillum frisingense sp. nov., a new nitrogen-fixing bacterial species that occurs in C4-fibre plants. Int $\mathrm{J}$ Syst Evol Microbiol. 51:157-168.

29. Konneke, M., A.E. Bernhard, J.R. de la Torre, C.B. Walker, J.B. Waterbury, and D.A. Stahl. 2005. Isolation of an autotrophic ammonia-oxidizing marine archaeon. Nature 437:543-546.

30. Lane, D.J. 1991. 16S/23S rRNA sequencing, p. 115-175. In E. Stackebrandt and M. Goodfellow (ed.), Nucleic Acid Techniques in Bacterial Systematics. Wiley, New York.

31. Larkin, M.A., G. Blackshields, N.P. Brown, et al. 2007. Clustal W and Clustal X version 2.0. Bioinformatics. 23:2947-2948.

32. Lovley, D., and E. Phillips. 1986. Availability of ferric iron for microbial reduction in bottom sediments of the freshwater tidal Potomac River. Appl Environ Microbiol. 52:751-757.

33. Lovley, D., and E. Phillips. 1987. Rapid assay for microbially reducible ferric iron in aquatic sediments. Appl Environ Microbiol. 53:1536-1540.
34. Lozupone, C., and R. Knight. 2005. UniFrac: a new phylogenetic method for comparing microbial communities. Appl Environ Microbiol. 71:8228-8235.

35. Lu, H., R. Fujimura, Y. Sato, K. Nanba, T. Kajimoto, and H. Ohta. 2008. Characterization of Herbaspirillum- and Limnobacter-related strains isolated from young volcanic deposits in Miyake-Jima Island, Japan. Microbes Environ. 23:66-72.

36. McCollom, T., and E. Shock. 1997. Geochemical constraints on chemolithoautotrophic metabolism by microorganisms in seafloor hydrothermal systems. Geochim Cosmochim Acta. 61:4375-4391.

37. Meyer-Dombard, D.A.R., J.P. Amend, and M.R. Osburn. 2012 Microbial diversity and potential for arsenic and iron biogeochemical cycling at an arsenic rich, shallow-sea hydrothermal vent (Tutum Bay, Papua New Guinea). Chem Geol. 348:37-47.

38. Mochizuki, T., M. Krupovic, G. Pehau-Arnaudet, Y. Sako, P. Forterre, and D. Prangishvili. 2012. Archaeal virus with exceptional virion architecture and the largest single-stranded DNA genome. Proc Natl Acad Sci. U.S.A. 109:13386-13391.

39. Mochizuki, T., T. Yoshida, R. Tanaka, P. Forterre, Y. Sako, and D. Prangishvili. 2010. Diversity of viruses of the hyperthermophilic archaeal genus Aeropyrum, and isolation of the Aeropyrum pernix bacilliform virus 1, APBV1, the first representative of the family Clavaviridae. Virology. 402:347-354.

40. Munch, J.C., and J.C.G. Ottow. 1980. Preferential reduction of amorphous to crystalline iron oxides by bacterial activity. Soil Science. 129:15-21.

41. Muyzer, G., A. Teske, C. Wirsen, and H. Jannasch. 1995. Phylogenetic relationships of Thiomicrospira species and their identification in deep-sea hydrothermal vent samples by denaturing gradient gel electrophoresis of 16S rDNA fragments Arch. Microbiol. 164:165-172.

42. Nakagawa, S., K. Takai, K. Horikoshi, and Y. Sako. 2004. Aeropyrum camini sp. nov., a strictly aerobic, hyperthermophilic archaeon from a deep-sea hydrothermal vent chimney. Int J Syst Evol Microbiol. 54:329-335.

43. Nakagawa, S., K. Takai, K. Horikoshi, and Y. Sako. 2003. Persephonella hydrogeniphila sp. nov., a novel thermophilic, hydrogen-oxidizing bacterium from a deep-sea hydrothermal vent chimney. Int J Syst Evol Microbiol. 53:863-869.

44. Pester, M., C. Schleper, and M. Wagner. 2011. The Thaumarchaeota: an emerging view of their phylogeny and ecophysiology. Curr Opin Microbiol. 14:300-306.

45. Pley, U., J. Schipka, A. Gambacorta, H.W. Jannasch, H. Fricke, R. Rachel, and K.O. Stetter. 1991. Pyrodictium abyssi sp. nov. represents a novel heterotrophic marine archaeal hyperthermophile growing at $110^{\circ} \mathrm{C}$. Syst Appl Microbiol. 14:245-253.

46. Price, R.E., and T. Pichler. 2005. Distribution, speciation and bioavailability of arsenic in a shallow-water submarine hydrothermal system, Tutum Bay, Ambitle Island, PNG. Chem Geol. 224:122-135.

47. Prol-Ledesma, R.M., C. Canet, M.A. Torres-Vera, M.J. Forrest, and M.A. Armienta. 2004. Vent fluid chemistry in Bahía Concepción coastal submarine hydrothermal system, Baja California Sur, Mexico. J Volcanol Geotherm Res. 137:311-328.

48. Reysenbach, A.-L.. 2001. Phylum BI. Aquificae phy. nov, p. 359367. In D. Boone and R. Castenholz (ed.), Bergey's Manual of Systematic Bacteriology. Springer, New York.

49. Reysenbach, A.-L., M. Ehringer, and K. Hershberger. 2000. Microbial diversity at $83^{\circ} \mathrm{C}$ in Calcite Springs, Yellowstone National Park: another environment where the Aquificales and "Korarchaeota" coexist. Extremophiles. 4:61-67.

50. Reysenbach, A.-L., G.S. Wickham, and N.R. Pace. 1994 Phylogenetic analysis of the hyperthermophilic pink filament community in Octopus Spring, Yellowstone National Park. Appl Environ Microbiol. 60:2113-2119.

51. Rogers, K.L., J.P. Amend, and S. Gurrieri. 2007. Temporal changes in fluid chemistry and energy profiles in the vulcano island hydrothermal system. Astrobiology. 7:905-932.

52. Rothballer, M., M. Schmid, I. Klein, A. Gattinger, S. Grundmann, and A. Hartmann. 2006. Herbaspirillum hiltneri sp. nov., isolated from surface-sterilized wheat roots. Int J Syst Evol Microbiol. 56:13411348 .

53. Sako, Y., N. Nomura, A. Uchida, Y. Ishida, H. Morii, Y. Koga, T. Hoaki, and T. Maruyama. 1996. Aeropyrum pernix gen. nov., sp. nov., a novel aerobic hyperthermophilic archaeon growing at temperatures up to 100 degrees C. Int J Syst Bacteriol. 46:1070-1077. 
54. Schleifer, K.H. 2009. Phylum XIII. Firmicutes Gibbons and Murray 1978. p. 19-1317. In P. Vos, G. Garrity, D. Jones, N. Krieg, W. Ludwig, F. Rainey, K.-H. Schleifer, and W. Whitman (ed.), Bergey's Manual of Systematic Bacteriology. Springer New York.

55. Shock, E., T. McCollom, and M. Schulte. 1995. Geochemical constraints on chemolithoautotrophic reactions in hydrothermal systems. Orig Life Evol Biosph 25:141-159.

56. Simmons, S., and P. Norris. 2002. Acidophiles of saline water at thermal vents of Vulcano, Italy. Extremophiles. 6:201-207.

57. Steinsbu, B.O., B.J. Tindall, V.L. Torsvik, I.H. Thorseth, F.L. Daae, and R.B. Pedersen. 2010. Rhabdothermus arcticus gen. nov., sp. nov., a novel member of the family Thermaceae isolated from a hydrothermal vent chimney from Soria Moria vent field at the Arctic Mid-Ocean Ridge. Int J Syst Evol Microbiol. 61:2197-2204.

58. Stetter, K.O., H. König, and E. Stackebrandt. 1983. Pyrodictium gen. nov., a new genus of submarine disc-shaped sulphur reducing archaebacteria growing optimally at $105^{\circ} \mathrm{C}$. Syst Appl Microbiol. 4:535-551.

59. Stookey, L.L. 1970. Ferrozine-a new spectrophotometric reagent for iron. Anal Chem. 42:779-781.

60. Sunamura, M., Y. Higashi, C. Miyako, J.-i. Ishibashi, and A Maruyama. 2004. Two Bacteria phylotypes are predominant in the Suiyo Seamount hydrothermal plume. Appl Environ Microbiol. 70:1190-1198.

61. Tanaka, R., S. Kawaichi, H. Nishimura, and Y. Sako. 2006. Thermaerobacter litoralis sp. nov., a strictly aerobic and thermophilic bacterium isolated from a coastal hydrothermal field. Int J Syst Evol Microbiol. 56:1531-1534.

62. Tanner, M.A., B.M. Goebel, M.A. Dojka, and N.R. Pace. 1998. Specific ribosomal DNA sequences from diverse environmental settings correlate with experimental contaminants. Appl Environ Microbiol. 64:3110-3113.
63. Tourna, M., M. Stieglmeier, A. Spang, et al. 2011. Nitrososphaera viennensis, an ammonia oxidizing archaeon from soil. Proc Natl Acad Sci U.S.A. 108:8420-8425.

64. Valverde, A., E. Velázquez, C. Gutiérrez, E. Cervantes, A. Ventosa, and J.-M. Igual. 2003. Herbaspirillum lusitanum sp. nov., a novel nitrogen-fixing bacterium associated with root nodules of Phaseolus vulgaris. Int J Syst Evol Microbiol. 53:1979-1983.

65. Ver Eecke, H.C., D.S. Kelley, and J.F. Holden. 2009. Abundances of hyperthermophilic autotrophic $\mathrm{Fe}$ (III) oxide reducers and heterotrophs in hydrothermal sulfide chimneys of the northeastern Pacific Ocean. Appl Environ Microbiol. 75:242-245.

66. Von Damm, K.L. 1995. Controls on the chemistry and temporal variability of seafloor hydrothermal fluids, p. 222-247, Seafloor Hydrothermal Systems: Physical, Chemical, Biological, and Geological Interactions, vol. 91. AGU, Washington, DC.

67. Wang, Q., G.M. Garrity, J.M. Tiedje, and J.R. Cole. 2007. Naïve Bayesian classifier for rapid assignment of rRNA sequences into the new bacterial taxonomy. Appl Environ Microbiol. 73:5261-5267.

68. Yoneda, Y., T. Yoshida, T. Daifuku, T. Kitamura, T. Inoue, S. Kano, and Y. Sako. 2013. Quantative detection of carboxydotrophic bacteria Carboxydothermus in a hot aquatic environment. Fundam Appl Limnol. 182:161-170

69. Yu, Y., M. Breitbart, P. McNairnie, and F. Rohwer. 2006. FastGroupII: a web-based bioinformatics platform for analyses of large 16S rDNA libraries. BMC Bioinformatics. 7:57.

70. Zillig, W., I. Holz, D. Janekovic, et al. 1990. Hyperthermus butylicus, a hyperthermophilic sulfur-reducing archaebacterium that ferments peptides. J Bacteriol. 172:3959-3965.

71. Zillig, W., I. Holz, and S. Wunderl. 1991. Hyperthermus butylicus gen. nov., sp. nov., a hyperthermophilic, anaerobic, peptidefermenting, facultatively $\mathrm{H}_{2} \mathrm{~S}$-generating archaebacterium. Int J Syst Bacteriol. 41:169-170. 